\title{
Why productive lakes are larger mercury sedimentary sinks than oligotrophic brown water lakes
}

\author{
MARTIN SCHUETZE ${ }^{1}$, BENJAMIN S. GILFEDDER ${ }^{2}$, \\ PHILIPP GATZ ${ }^{1}$ AND HARALD UWE BIESTER ${ }^{1}$ \\ ${ }^{1}$ Technische Universität Braunschweig \\ ${ }^{2}$ University of Bayreuth \\ Presenting Author: h.biester@tu-braunschweig.de
}

Mercury accumulation in lake sediments is a widespread environmental problem due to the biomagnification of $\mathrm{Hg}$ in the aquatic food chain. Soil $\mathrm{Hg}$ concentrations, catchment vegetation, erosion and lake productivity are major factors controlling the accumulation of $\mathrm{Hg}$ in lakes. However, their influence on the $\mathrm{Hg}$ mass balance in lakes with different catchment characteristics and trophic state is poorly understood. In this multi-lake study, we decipher the effects of catchment vegetation (coniferous versus deciduous forest), soil $\mathrm{Hg}$ content and trophic state on $\mathrm{Hg}$ sedimentation at six lakes in Germany. We investigated $\mathrm{Hg}$ concentrations in leaves, soils and the lakes' water phase. $\mathrm{Hg}$ sedimentation rates were derived from sediment trap analyses. Soils under coniferous stands show slightly higher $\mathrm{Hg}$ concentrations than under deciduous forest. $\mathrm{Hg}$ concentrations in the water phase were higher in the oligotrophic brown water lakes at the coniferous forest sites $\left(8.1 \pm 5.6 \mathrm{ng} \mathrm{L}^{-1}\right.$ versus $3.0 \pm 1.9 \mathrm{ng} \mathrm{L}^{-1}$ ). Lower $\mathrm{Hg}$ concentrations in sediment trap material indicate dilution by algae organic matter in the mesotrophic lakes at the deciduous sites $\left(0.12-0.17 \mu \mathrm{g} \mathrm{g}^{-1}\right.$ versus $\left.0.57-0.89 \mu \mathrm{g} \mathrm{g}^{-1}\right)$. However, $\mathrm{Hg}$ accumulation rates in sediment traps were up to fourteenfold higher in the deciduous forest lakes (113-443 $\left.\mu \mathrm{g} \mathrm{m}^{-2} \mathrm{y}^{-1}\right)$ than in the brown water lakes (32-144 $\mu \mathrm{g}$ $\left.\mathrm{m}^{-2} \mathrm{y}^{-1}\right)$, which could not be explained by higher $\mathrm{Hg}$ fluxes to the productive lakes. $\mathrm{Hg}$ mass balance calculation reveal that water phase $\mathrm{Hg}$ scavenging by algae is the major reason for the intense $\mathrm{Hg}$ export to the sediments of productive lakes which makes them significantly larger sedimentary sinks than oligotrophic brown water lakes. 